\title{
液体クロマトグラフィー/質量分析法を用いる 環境水中副腎皮質ステロイド類分析法の開発
}

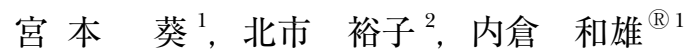

\begin{abstract}
環境試料中に含まれる副腎皮質ステロイド類の液体クロマトグラフィー/質量分析（LC/MS）法を確立し， 河川水に適用した，測定対象とした副腎皮質ステロイドは，プレドニゾロン，デキサメタゾン，ベタメタゾ ン，トリアムシノロンアセトニド，フルオシノロンアセトニド，酢酸プレドニゾロン，酢酸ヒドロコルチゾ ン, 吉草酸ベタメタゾン及び二プロピオン酸ベタメタゾンの 9 種である. 採水した河川水はガラス瀻維沪紙 で沪過した後，沪液からの測定対象物質の抽出及び濃縮を固相抽出法で行った．溶出にはアセトニトリル $5 \mathrm{~mL}$ を用い，この溶液を濃縮し，アセトニトリルで溶解して $1 \mathrm{~mL}$ としたものを LC/MS に注入した．移動 相はアセトニトリルー酰酸アンモニウム緩衝液を用いてグラジェント溶離し， MS で検出した。最適条件下， 作成した各測定対象物質の検量線は相関倸数 0.9971 以上の直線性を示し, 検出限界は $S / N=3$ とした時 0.7 〜 $2.4 \mathrm{ng} / \mathrm{L}$ であった．また，本測定法を河川水に適用した結果， $10 \mathrm{ng} / \mathrm{L}$ の添加回収試験において回収率は 56.2 〜10\% であった.
\end{abstract}

\section{1 緒言}

内分泌擋乱化学物質が日本において話題となって久しい が, 近年欧米において, emerging contaminants（新規污染 物質）のひとつとして，医薬品の環境への影響が注目され てきている1．医薬品は医療機関だけでなく，水産や畜産 分野，ペット等の動物用としても多用されている。 これら は多くの成分が使用されており，規制されることなく家庭 や工場，医療機関等から下水処理場を経て，又は直接，環 境水中に排出されている。 ヒトや動物が服用した医薬品 は，代謝して排出されるとも限らず，一部は代謝されずに 薬の活性を有したままで排出されることもある。このよう な未変化体のまま排出される医薬品の割合や下水処理場で の除去率は物質の種類によって異なると考えられる，本 来, 医薬品は生理作用を目的として使用される物質である ため, 環境水中に存在する極微量の医薬品が生態系に与え る影響が関心を集めている，医薬品の中でも，細菌等の微 生物に作用する医薬品がヒトや動物を介して環境中に排出 されると, これらの薬剤に耐性を持つ薬剤耐性菌が現れ, 環境中に広がり, 新たな感染病が発症する可能性がある.

欧米においては, ここ数年で環境中から数多くの医薬品

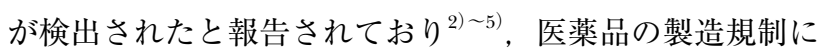
環境リスク評価を組み込むことが提案されている ${ }^{6 / 7}$. 我が

\footnotetext{
${ }^{1}$ 日本大学薬学部：274-8555 千葉県船橋市習志野台 7-7-1

2 日本大学大学院薬学研究科 : $274-8555$ 千葉県船橋市習志野台 $7-7-1$
}

国においても環境中に放出される医薬品に関する認識は 徐々に高まりつつあるが，報告例は数少な( ${ }^{8) \sim 10)}$ ．また， 人に用いられる医薬品は薬事法の規制を受けているが，化 学物質の審査及び製造等の規制に関する法律（化審法）で は適用外となっており，環境影響に基づいた審査，規制は されていないのが現状である，今後，医薬品の適正使用を 考える中で, 環境中に存在する医薬品の種類及び濃度のデ ータが必要であると考えられる。

これまでに環境中の濃度を調査されている医薬品は, 解 熱・鎮痛剤，抗てんかん剂等があるが，抗炎症等の治療に 沉用されている副腎皮質ステロイド類については，ほとん ど調査されていない. 平成 14 年薬事工業生産動態統計年 報11によよと, 医療用医薬品の出荷量は, プレドニゾロン (1.9 t/year)，デキサメタゾン (18 kg/year)，ベタメタゾン (18 kg/year)，トリアムシノロンアセトニド $(9 \mathrm{~kg} /$ year $)$, フルオシノロンアセトニド (3 kg/year), 吉草酸ベタメ夕 ゾン $(52 \mathrm{~kg} / \mathrm{year})$ ，ジプロピオン酸ベタメタゾン $(18 \mathrm{~kg} /$ year）であるといわれている。 このほかに，作用の弱い副 腎皮質ステロイド類が一般用医薬品としても販売されてお り，広く使用されている，外用薬として用いる副腎皮質又 テロイド類は経皮で吸収され，主に局所作用により薬効を 表すが, 経口での服用と違い吸収されなかった薬が生体内 を経由せず，直接洗い流される等して環境中に放出される 可能性が高いと考えられる.

したがって，本研究では外用薬として多用される副腎皮 質ステロイド類に着目して環境試料中の分析方法を確立 
<smiles>C[C@@]12C=CC(=O)C=C1CC[C@H]1[C@@H]3CC[C@](O)(C(=O)CO)[C@@]3(C)C[C@H](O)[C@H]12</smiles>

Prednisolone

Mw: 360.5 Log P: 1.62

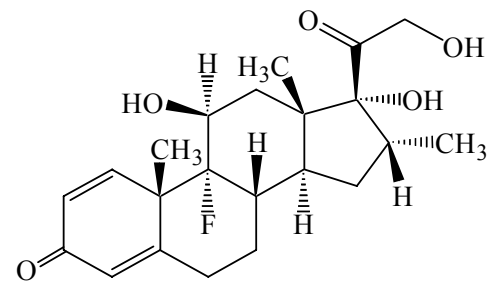

Dexamethasone

Mw: 392.5 Log P: 1.83

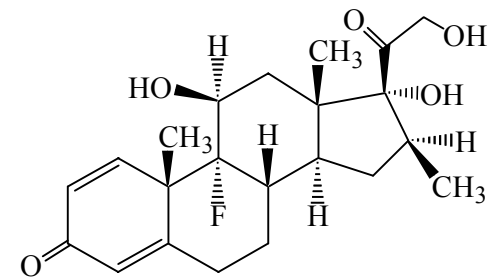

Betamethasone Mw: 392.5 Log P: 1.94

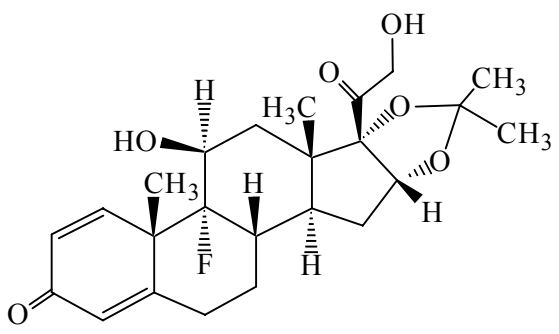

Triamcinolone acetonide Mw: 434.5 Log P: 2.53<smiles>CC(=O)OCC(=O)[C@@]1(O)CC[C@H]2[C@H]3[C@H](CCC4=CC(=O)C=C[C@@]43C)[C@H](O)C[C@@]21C</smiles>

Prednisolone acetate

Mw: 402.5 Log P: 2.40

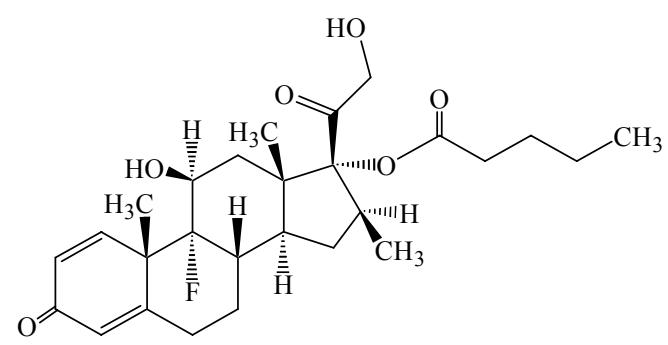

Betamethasone valerate Mw: 476.6 Log P: 3.60

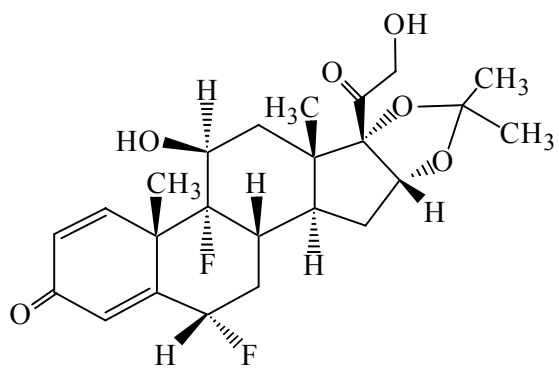

Fluocinolone acetonide Mw: 452.5 Log P: 2.48<smiles>CC(=O)OCC(=O)[C@]1(O)CC[C@H]2[C@H]3[C@H](O)[C@H](O)C[C@]2(C)[C@H]3CCC2=CC(=O)CC[C@@]21C</smiles>

Hydrocortisone acetate Mw: 404.5 Log P: 2.19<smiles>CCC(=O)O[C@]1(C(=O)OC(C)=O)[C@@H](C)C[C@H]2[C@H]3CCC4=CC(=O)C=C[C@]4(C)[C@H]3[C@H](O)C[C@]21C</smiles>

Betamethasone dipropionate Mw: 505.6 Log P: 4.07

Fig. 1 Chemical structures of target compounds

し，河川水について適用した。

$$
2 \text { 実験 }
$$

\section{$\mathbf{2} \cdot \mathbf{1}$ 試 薬}

今回測定した分析対象物質の構造を Fig. 1 に示す. 標準 品として使用したプレドニゾロン，デキサメタゾン，ベタ メタゾン, トリアムシノロンアセトニド, 酢酸プレドニゾ
ロン, 酢酸ヒドロコルチゾン, 吉草酸ベタメタゾン, 二プ ロピオン酸ベタメタゾンは和光純薬製を用いた. アセトニ トリル〔高速液体クロマトグラフィー（HPLC）及び液体 クロマトグラフィー/質量分析（LC/MS）用]及びメタノ ール (特級) は和光純薬工業製を, フルオシノロンアセト ニドは ICN Biomedicals 製を用い，その他の試薬は試薬特 級品を用いた．沪紙はWhatman 製の GLASS MICROFIBRE 
Table 1 Typical ions detected for target compounds using LC/MS

\begin{tabular}{|c|c|c|c|c|}
\hline \multirow[b]{2}{*}{ Prednisolone } & \multirow{2}{*}{$\begin{array}{c}\mathrm{Mw} \\
360.5\end{array}$} & Base peak ions & \multicolumn{2}{|c|}{ Other ions } \\
\hline & & {$[\mathrm{M}+\mathrm{H}]^{+} \quad 361$} & {$[\mathrm{M}+\mathrm{K}]^{+}$} & 399 \\
\hline Dexamethasone & 392.5 & {$[\mathrm{M}+\mathrm{H}]^{+} 393$} & {$[\mathrm{M}+\mathrm{K}]^{+}$} & 431 \\
\hline Betamethasone & 392.5 & {$[\mathrm{M}+\mathrm{H}]^{+} 393$} & {$[\mathrm{M}+\mathrm{K}]^{+}$} & 431 \\
\hline Triamcinolone acetonide & 434.5 & {$[\mathrm{M}+\mathrm{H}]^{+} \quad 435$} & {$[\mathrm{M}+\mathrm{K}]^{+}$} & 473 \\
\hline Fluocinolone acetonide & 452.5 & {$[\mathrm{M}+\mathrm{H}]^{+} \quad 453$} & {$[\mathrm{M}+\mathrm{K}]^{+}$} & 491 \\
\hline Prednisolone acetate & 402.5 & {$[\mathrm{M}+\mathrm{H}]^{+} \quad 403$} & {$[\mathrm{M}+\mathrm{K}]^{+}$} & 441 \\
\hline Hydrocortisone acetate & 404.5 & {$[\mathrm{M}+\mathrm{H}]^{+} \quad 405$} & {$[\mathrm{M}+\mathrm{K}]^{+}$} & 443 \\
\hline Betamethasone valerate & 476.6 & {$[\mathrm{M}+\mathrm{H}]^{+} \quad 477$} & {$[\mathrm{M}+\mathrm{K}]^{+}$} & 515 \\
\hline Betamethasone dipropionate & 504.6 & {$[\mathrm{M}+\mathrm{H}]^{+} \quad 505$} & {$[\mathrm{M}+\mathrm{K}]^{+}$} & 543 \\
\hline
\end{tabular}

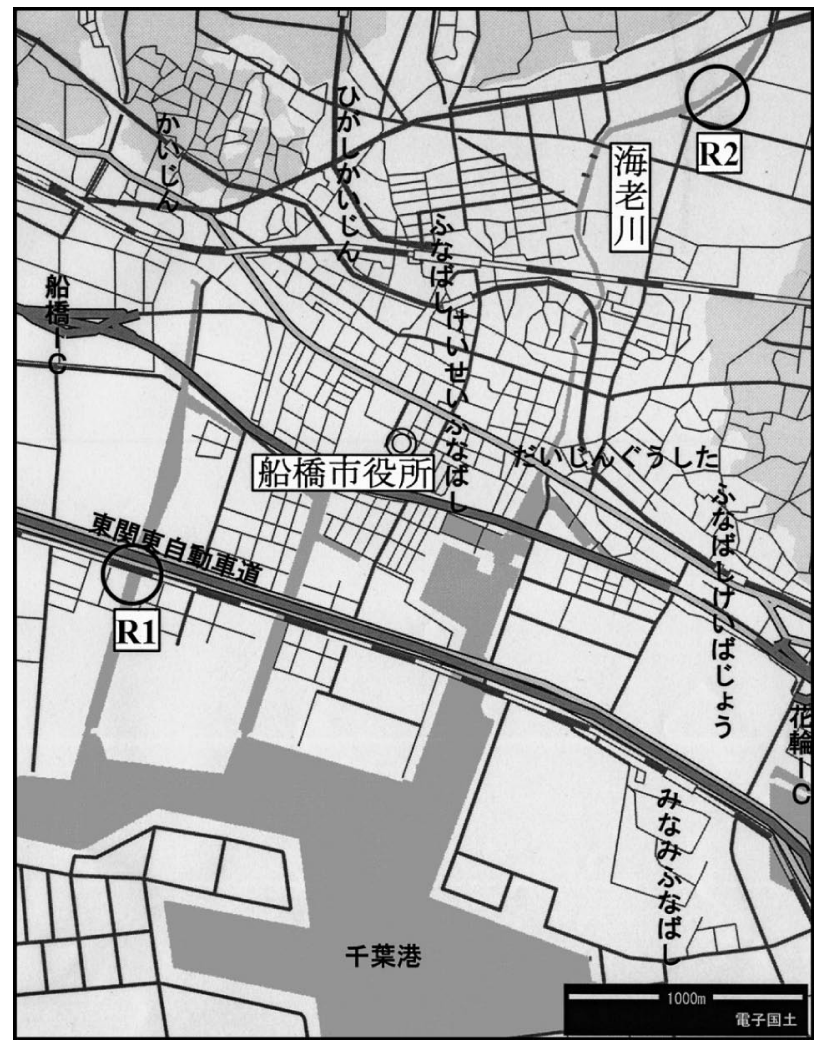

Fig. 2 Location of sampling points of river water Citation : "Denshi Kokudo" < http://cyberjapan.jp/>

FILTER GF/C $47 \mathrm{~mm} \phi$ を用い, カートリッジカラムは Waters 製の Sep-Pak ${ }^{\circledR}$ C18, OASIS ${ }^{\circledR}$ HLB 及び GL サイエン ス製の GL-PAK PLS2 を用いた. 水は SA-2000E (EYELA 製) 及び Milli-Q超純水装置 (日本ミリポア製)により精製して 用いた。

\section{$2 \cdot 2$ 標準溶液の調製}

それぞれの標準原液は $1000 \mu \mathrm{g} / \mathrm{mL}$ に調製した。デキサ メタゾン, ベタメタゾン, 酢酸プレドニゾロン, 酢酸ヒド ロコルチゾン, フルオシノロンアセトニド, 吉草酸ベタメ タゾン, 二プロピオン酸ベタメタゾンはアセトニトリルで
溶解し, プレドニゾロンはアセトニトリル及び少量のエ夕 ノール，トリアムシノロンアセトニドはアセトニトリル及 び少量のメタノールで溶解した. また, 混合標準原液 (100 $\mu \mathrm{g} / \mathrm{mL})$ は 9 種類の標準原液とアセトニトリルを混合し, 標準溶液は混合標準原液を 1 〜 $1000 \mathrm{ng} / \mathrm{mL}$ に用時希釈し て用いた。

\section{$2 \cdot 3$ 装置及び測定条件}

2・3・1 HPLC 装置は LC-10AD システム（島津製作 所製）を使用し， $260 \mathrm{~nm}$ の吸光度を測定した. カラムは Synergi $4 \mu$ Hydro-RP 80A $(150 \times 4.6 \mathrm{~mm}$, Phenomenex 製）を用い, カラム温度 $37^{\circ} \mathrm{C}$ とした. 移動相は $\mathrm{A}$ ：アセ卜 ニトリル， B：10 mM 酢酸アンモニウム緩衝液（pH 5.0） を用い，グラジェント溶離とした。グラジェント条件は次

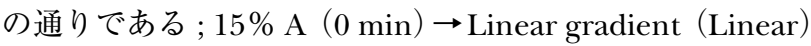
$28 \%$ A $(5 \mathrm{~min}) \rightarrow$ Linear $32 \%$ A $(20 \mathrm{~min}) \rightarrow$ Linear $55 \%$ A $(10 \mathrm{~min}) \rightarrow$ Const. $(15 \mathrm{~min})$.また, 流量は $1 \mathrm{~mL} / \mathrm{min}$, 注 入量は $20 \mu \mathrm{L}$ とした.

2・3・2 LC/MS LC/MS 装置は Agilent 1100 Series を 使用し, カラムは Synergi $4 \mu$ Hydro-RP 80A $(150 \times 3.0 \mathrm{~mm}$, Phenomenex 製) を使用した。移動相は HPLC と同様の条 件を用い, 流量 $0.4 \mathrm{~mL} / \mathrm{min}$, 注入量 $10 \mu \mathrm{L}$ で分析を行っ た. 質量分析はエレクトロスプレーイオン化法 (ESI) ポジ ティブイオンモードを用いた. 乾燥ガス流量 $\mathrm{N}_{2}$ ガス 10 $\mathrm{L} / \mathrm{min}$, 乾燥ガス温度 $350^{\circ} \mathrm{C}$, ネブライザー圧力 $40 \mathrm{psig}$, キャピラリー電圧 $3000 \mathrm{~V}$, フラグメンター電圧 $125 \mathrm{~V}$ とし た. 各測定対象物質の定量イオン（base peak ions）及び確 認イオン（other ions）を Table 1 に示す.

\section{$2 \cdot 4$ 実試料への応用}

実試料は 2005 年 11 月 4 日に千葉県船橋市内の 2 箇所の 河川水を褐色ガラス瓶に採水し, 速やかに分析を行った. 採水地点 R1 及び R2 を Fig. 2 に示す.

また, 実試料の前処理操作は, 初めに採水した河川水の 各 $1 \mathrm{~L}$ をガラス繊維沪紙で沪過をし，沪液を Sep-Pak ${ }^{\circledR} \mathrm{C} 18$ カートリッジカラムに $5 \sim 6 \mathrm{~mL} / \mathrm{min}$ で通水した. その後, 
Table 2 Investigated gradient conditions

\begin{tabular}{|c|c|c|}
\hline No. & Conditions & $\begin{array}{c}\text { Resolution }(R s) \text { of } \\
\text { Dexamethasone and Betamethasone }\end{array}$ \\
\hline 1 & $25 \%$ A $(0 \mathrm{~min}) \rightarrow$ Linear $32 \%$ A $(20 \mathrm{~min}) \rightarrow$ Const. $(15 \mathrm{~min})$ & 0.79 \\
\hline 2 & $15 \%$ A $(0 \mathrm{~min}) \rightarrow$ Linear $32 \%$ A $(15 \mathrm{~min}) \rightarrow$ Const. $(20 \mathrm{~min})$ & 0.98 \\
\hline 3 & $15 \%$ A $(0 \mathrm{~min}) \rightarrow$ Linear $35 \%$ A $(20 \mathrm{~min}) \rightarrow$ Const. $(15 \mathrm{~min})$ & 1.24 \\
\hline 4 & $15 \%$ A $(0 \mathrm{~min}) \rightarrow$ Linear $25 \%$ A $(5 \mathrm{~min}) \rightarrow$ Linear $32 \%$ A $(15 \mathrm{~min}) \rightarrow$ Const. $(15 \mathrm{~min})$ & 1.35 \\
\hline 5 & $15 \%$ A $(0 \mathrm{~min}) \rightarrow$ Linear $28 \%$ A ( 5 min $) \rightarrow$ Linear $32 \%$ A (15 min $) \rightarrow$ Const. ( 15 min $)$ & 1.43 \\
\hline 6 & $15 \%$ A $(0 \mathrm{~min}) \rightarrow$ Linear $28 \%$ A ( 5 min $) \rightarrow$ Linear $32 \%$ A $(20 \mathrm{~min}) \rightarrow$ Const. $(10 \mathrm{~min})$ & 1.46 \\
\hline 7 & $5 \%$ A $(0 \mathrm{~min}) \rightarrow$ Linear $35 \%$ A $(15 \mathrm{~min}) \rightarrow$ Const. $(15 \mathrm{~min})$ & 1.01 \\
\hline
\end{tabular}

A : Acetonitrile ; Linear : Linear gradient ; Const. : Constant

カートリッジカラムを精製水 $10 \mathrm{~mL}$ で洗浄し，アセトニト リル $5 \mathrm{~mL}$ で測定対象物質を溶出した. Sep-Pak ${ }^{\circledR} \mathrm{C} 18$ はア

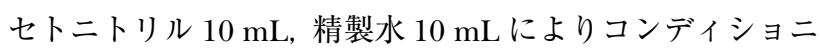
ングしたものを用いた. この溶出液を濃縮し, アセトニト リルで溶解して $1 \mathrm{~mL}$ としものを HPLC試料溶液とした.

\section{3 結果及び考察}

\section{$3 \cdot 1$ 分離条件の検討}

初めにHPLCを用いてデキサメタゾン, ベタメタゾン, 酢酸プレドニゾロン，トリアムシノロンアセトニド，フル オシノロンアセトニド, 酢酸ヒドロコルチゾンの極性が近 い6 成分について分離条件の検討を行った. 移動相にアセ トニトリルと水の混液を用い分離を行ったところ, カラム の保持が強くブロードなピークを示した. これを改善する ために，移動相に酢酸アンモニウムを添加したところ，ピ ーク形状の改善が認められたため, $10 \mathrm{mM}$ 酢酸アンモニウ ムとアセトニトリルの混液を移動相として用いた.

また，デキサメタゾンとベタメタゾンは異性体であるた め, LC/MS で検出する際に, 分子量による分別定量が不可 能である。したがって，この 2 成分の分離が良好となるよ うに分離条件の検討を行った. まず，アセトニトリル含量 を 25 ４0％の範囲で変化させた移動相を用いてアイソク ラティック分析を行い, 分離挙動を比較した。 その結果, アセトニトリルの割合を減らすことによりデキサメタゾン とベタメタゾンのピークは徐々に分離したが, 分離度 （Rs）はアセトニトリル含量 $25 \%$ を用いた場合 $0.90,30 \%$ では $0.58,35 \%$ 以上においては 0.00 であった。また， Rs が一番良好であったアセトニトリル含量 $25 \%$ の条件にお いては各成分の保持が強まり, すべての成分が溶出するま でに 1 時間以上必要であったため, アイソクラティック溶 出法では良好な分離が得られなかった。したがって, 分析 時間の短縮及び良好な分離を得るために，グラジエント分 離について検討を行った. 検討した 7 種のグラジエント条 件及びデキサメタゾンとベタメタゾンの Rs Table 2 に示 す. すべての成分が 30 分前後で溶出するように, アセトニ トリルの最終的な割合を $32 〜 35 \%$ とした.
検討の結果, Table 2 に示すように, ベタメタゾンとデキ サメタゾンの Rs が 1.46 と一番高くなったグラジエント条 件 6 を用い分離を行うことにした. 更に, プレドニゾロン, 吉草酸ベタメタゾン, 二プロピオン酸ベタメタゾンの 3 成 分を加えた 9 成分を分離するために，グラジエント条件 6 を変更し $2 \cdot 3 \cdot 1$ で示した分離条件とした.

\section{$3 \cdot 2$ 前処理条件の検討}

試料水からの測定対象物質の抽出及び濃縮には，固相抽 出法を採用した. 固相抽出カートリッジには, Sep-Pak C18, GL-Pak PLS2, OASIS ${ }^{\circledR}$ HLB を使用し検討を行った. また，溶出溶媒としては，アセトニトリル及びメタノール について検討した，試料溶液は，標準溶液を $2 \mu \mathrm{g} / \mathrm{L}$ とな るように精製水で希棌して用い，2・4 で示した操作法で前 処理を行った.

それぞれのカートリッジカラムにおける回収率及び相対 標準偏差（RSD，％）を Table 3 及び 4 に示す。検討した 結果アセトニトリルとメタノールについては, 回収率に大 きな差は認められなかったが, メタノールを用いるよりも アセトニトリルを用いたほうが再現性が良好であったた め, 溶出溶媒はアセトニトリルを用いた. 固相抽出カート リッジについては OASIS ${ }^{\circledR}$ HLB では回収率, 再現性共に低 く，GL-Pak PLS2 では，回収率は良好であるが，再現性が 低かった. Sep-Pak ${ }^{\circledR} \mathrm{C} 18$ については, 回収率, 再現性共に 優れていたのでこれを採用した.

\section{$3 \cdot 3 \mathrm{LC} / \mathrm{MS}$ 条件の検討}

現在, LC/MS のイオン化法としてエレクトロスプレー イオン化法（ESI）及び大気圧化学イオン化法（APCI）が 多用されている. ESI は, 最もソフトなイオン化法で熱不 安定物質や中〜高極性化合物へ適用される. APCI は中〜 低極性化合物の分析に適しているが，試料溶液を高温 （200〜 $500^{\circ} \mathrm{C}$ 程度）に加熱するため, 熱に不安定な物質に は適していない ${ }^{1213)}$. 本研究に用いた測定対象物質は，極 性が高く (Fig. 1)， $200^{\circ} \mathrm{C}$ 前後で分解する物質 ${ }^{14)}$ が多いた め, イオン化には ESI を選択し, フローインジェクション 
Table 3 Recovery of target compounds by cartridge column and acetonitrile

\begin{tabular}{|c|c|c|c|c|c|c|}
\hline \multirow{3}{*}{ Compound } & \multicolumn{6}{|c|}{ Cartridge column } \\
\hline & \multicolumn{2}{|c|}{ Sep-Pak ${ }^{\circledast}$ C18 } & \multicolumn{2}{|c|}{ OASIS $^{\circledast}$ HLB } & \multicolumn{2}{|c|}{ GL-Pak PLS2 } \\
\hline & $\begin{array}{c}\text { Recovery, } \\
\%\end{array}$ & $\begin{array}{c}\text { RSD, } \\
\%(n=3)\end{array}$ & $\begin{array}{c}\text { Recovery, } \\
\%\end{array}$ & $\begin{array}{c}\text { RSD, } \\
\%(n=3)\end{array}$ & $\begin{array}{c}\text { Recovery, } \\
\%\end{array}$ & $\begin{array}{c}\text { RSD, } \\
\%(n=3)\end{array}$ \\
\hline Prednisolone & 92.6 & 3.5 & 87.5 & 12.5 & 102 & 6.8 \\
\hline Dexamethasone & 97.1 & 4.8 & 85.7 & 10.8 & 101 & 7.3 \\
\hline Betamethasone & 94.6 & 3.8 & 85.1 & 8.9 & 94.4 & 6.5 \\
\hline Triamcinolone acetonide & 96.0 & 0.7 & 89.3 & 10.2 & 103 & 7.4 \\
\hline Fluocinolone acetonide & 125 & 4.6 & 107 & 7.9 & 103 & 8.8 \\
\hline Prednisolone acetate & 99.5 & 1.4 & 91.7 & 11.1 & 103 & 6.9 \\
\hline Hydrocortisone acetate & 95.5 & 1.5 & 86.8 & 11.0 & 104 & 7.1 \\
\hline Betamethasone valerate & 89.5 & 2.6 & 85.2 & 5.2 & 99.2 & 6.7 \\
\hline Betamethasone dipropionate & 82.4 & 1.3 & 79.4 & 5.8 & 107 & 9.2 \\
\hline
\end{tabular}

RSD : Relative standard deviation

Table 4 Recovery of target compounds by cartridge column and methanol

\begin{tabular}{|c|c|c|c|c|c|c|}
\hline \multirow{3}{*}{ Compound } & \multicolumn{6}{|c|}{ Cartridge column } \\
\hline & \multicolumn{2}{|c|}{ Sep-Pak ${ }^{\circledR}$ C18 } & \multicolumn{2}{|c|}{ OASIS $^{\circledR}$ HLB } & \multicolumn{2}{|c|}{ GL-Pak PLS2 } \\
\hline & $\begin{array}{c}\text { Recovery, } \\
\%\end{array}$ & $\begin{array}{c}\text { RSD, } \\
\%(n=3)\end{array}$ & $\begin{array}{c}\text { Recovery, } \\
\%\end{array}$ & $\begin{array}{c}\text { RSD, } \\
\%(n=3)\end{array}$ & $\begin{array}{c}\text { Recovery, } \\
\%\end{array}$ & $\begin{array}{c}\text { RSD, } \\
\%(n=3)\end{array}$ \\
\hline Prednisolone & 101.1 & 1.7 & 81.7 & 6.6 & 89.9 & 17.4 \\
\hline Dexamethasone & 97.2 & 2.7 & 85.1 & 5.4 & 88.0 & 16.5 \\
\hline Betamethasone & 90.1 & 3.4 & 92.9 & 3.3 & 117.7 & 38.7 \\
\hline Triamcinolone acetonide & 96.8 & 3.0 & 77.8 & 6.9 & 82.6 & 16.2 \\
\hline Fluocinolone acetonide & 101.9 & 2.7 & - & - & - & - \\
\hline Prednisolone acetate & 98.2 & 3.6 & 75.2 & 5.8 & 82.5 & 16.1 \\
\hline Hydrocortisone acetate & 96.7 & 4.2 & 76 & 5.9 & 78.6 & 13.9 \\
\hline Betamethasone valerate & 72.1 & 10.2 & 79.5 & 7.5 & 82.3 & 14.0 \\
\hline Betamethasone dipropionate & 81.1 & 3.9 & 76.7 & 9.3 & 90.8 & 9.7 \\
\hline
\end{tabular}

RSD : Relative standard deviation

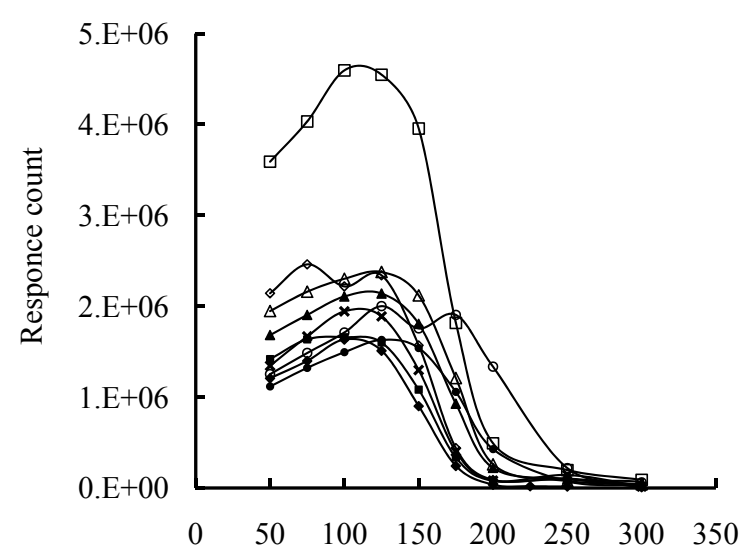

Fragmentor voltage / V

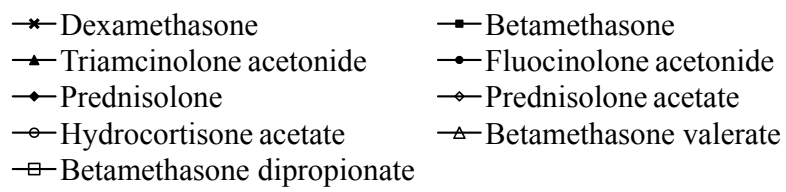

Fig. 3 Effect of fragmentor voltage on the MS detector response of $[\mathrm{M}+\mathrm{H}]^{+}$of target compounds
法によりポジティブ及びネガティブイオンモードで SCAN 測定を行った。 その結果, すべての成分においてポジティ ブイオンモードがネガティブイオンモードに比べ高感度で あったため, ポジティブイオンモードを採用した．次に， 最適なフラグメンター電圧及び定量に用いる質量数を決定 するために, フラグメンター電圧を 50 〜 $300 \mathrm{~V}$ の範囲で検 討した. 結果を Fig. 3 に示す. すべての化合物において 100 〜 $150 \mathrm{~V}$ の範囲で $[\mathrm{M}+\mathrm{H}]^{+}$の強度が高かったため, フラ グメンター電圧は $125 \mathrm{~V}$ とした。 また定量イオンには, 最 も高い強度を示した $[\mathrm{M}+\mathrm{H}]^{+}$を用いることとし, 次に強 度が高い $[\mathrm{M}+\mathrm{K}]^{+}$を確認イオンに使用することとした。

\section{$3 \cdot 4$ 直線性及び検出限界}

5〜 $100 \mathrm{ng} / \mathrm{L}$ の標準溶液を用いて各測定対象物質の直 線性を調べた結果, 相関係数 $(r) 0.9971$ 以上の直線性を 示した. 検出限界は $S / N=3$ として求め, $0.7 \sim 2.4 \mathrm{ng} / \mathrm{L}$ であった (Table 5). $5 \mathrm{ng} / \mathrm{L}$ を注入したときの各化合物の 選択イオン検出（SIM）クロマトグラムを Fig. 4 に示す. 


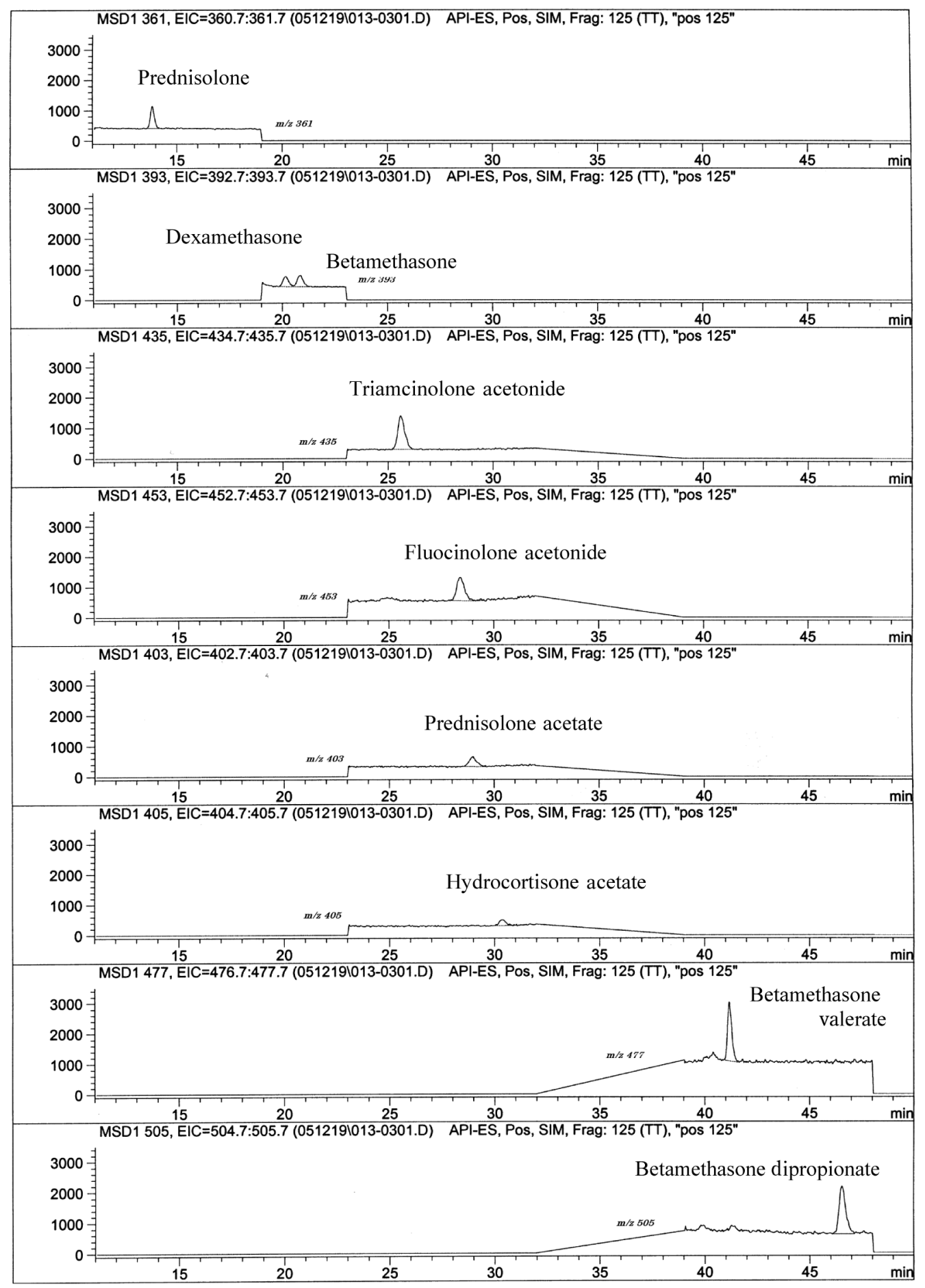

Fig. 4 Chromatogram of target compounds in standard solution with SIM mode $\left([\mathrm{M}+\mathrm{H}]^{+}\right)$

\section{$3 \cdot 5$ 添加回収試験}

添加回収試験には標準溶液を $10 \mathrm{ng} / \mathrm{L}$ となるように精製 水で希釈した溶液を用いた。 これを $2 \cdot 4$ の操作法に従って 繰り返し試験を行い, 回収率及び RSD, 定量下限を算出し た（Table 5)。回収率及び RSD はそれぞれ 77.6〜 103.4\% 及び $2.1 〜 12.1 \%$ と良好な結果が得られた，定量下限 $(S / N=10)$ は, すべての化合物において $10 \mathrm{ng} / \mathrm{L}$ 以下で あり, 高感度な定量が可能であった.

\section{$3 \cdot 6$ 実試料の測定}

$3 \cdot 6 \cdot 1$ 河川水への添加回収試験 二地点で採水した 河川水試料に，それぞれ標準溶液を $10 \mathrm{ng} / \mathrm{L}$ となるように 添加し, 測定を行い, 回収率を算出した（Table 6). 回収 率は $56.2 〜 110 \%$ の範囲となった.

$\mathbf{3 \cdot 6 \cdot 2}$ 河川水の測定 Fig. 2 に示した 2 地点で河川水 を採水し，測定を行った．測定結果を Table 6 に示し， R2 地点で採水したサンプル及びそのサンプルに標準溶液を 
Table 5 Validation of target compounds

\begin{tabular}{lccccc}
\hline \multicolumn{1}{c}{ Compound } & $r^{\mathrm{a})}$ & $\begin{array}{c}\text { Recovery } \\
\%\end{array}$ & $\begin{array}{c}\mathrm{RSD}^{\mathrm{b})}, \\
\%(n=5)\end{array}$ & $\begin{array}{c}\mathrm{LOD}^{\mathrm{a})} / \\
\mathrm{ng} \mathrm{L}^{-1}(S / N=3)\end{array}$ & $\begin{array}{c}\mathrm{LOQ}^{\mathrm{b})} / \\
\mathrm{ng} \mathrm{L}^{-1}(S / N=10)\end{array}$ \\
\hline Prednisolone & 0.9985 & 84.8 & 8.7 & 1.0 & 3.1 \\
Dexamethasone & 0.9971 & 85.9 & 6.9 & 1.7 & 5.2 \\
Betamethasone & 0.9985 & 86.5 & 5.8 & 1.5 & 4.3 \\
Triamcinolone acetonide & 0.9998 & 88.3 & 3.1 & 0.7 & 6.4 \\
Fluocinolone acetonide & 0.9995 & 89.5 & 2.1 & 1.6 & 8.4 \\
Prednisolone acetate & 0.9999 & 94.0 & 9.7 & 2.4 & 7.1 \\
Hydrocortisone acetate & 0.9996 & 103.4 & 6.1 & 1.9 & 2.0 \\
Betamethasone valerate & 0.9971 & 86.3 & 4.9 & 0.7 & 1.4 \\
Betamethasone dipropionate & 0.9992 & 77.6 & 12.1 & 0.7 & \\
\hline
\end{tabular}

a) Standard solution of target compounds. b) Target compounds added to pure water. $r$ : Correlation coefficient ; RSD : Relative standard deviation ; LOD : Limit of detection ; LOQ : Limit of quantitation

Table 6 Concentrations and recovery rates of target compounds in river water

\begin{tabular}{lcccccc}
\hline \multirow{2}{*}{ Compound } & \multicolumn{2}{c}{ Concentration $/ \mathrm{ng} \mathrm{L}^{-1}$} & & \multicolumn{2}{c}{ Recovery, \% } \\
\cline { 2 - 3 } \cline { 5 - 6 } & $\mathrm{R} 1$ & $\mathrm{R} 2$ & & $\mathrm{R} 1$ & $\mathrm{R} 2$ \\
\hline Prednisolone & n.d. & n.d. & & 79.3 & 58.4 \\
Dexamethasone & n.d. & trace & & 110 & 81.3 \\
Betamethasone & n.d. & trace & & 99.4 & 62.2 \\
Triamcinolone acetonide & n.d. & n.d. & & 79.7 & 88.3 \\
Fluocinolone acetonide & n.d. & n.d. & & 86.7 & 102 \\
Prednisolone acetate & n.d. & n.d. & & 85.2 & 103 \\
Hydrocortisone acetate & trace & & 8.6 & & 84.7 & 73.1 \\
Betamethasone valerate & trace & 2.6 & & 84.0 & 56.2 \\
Betamethasone dipropionate & n.d. & n.d. & & 97.8 & 98.6 \\
\hline n.d. : Not detected ; trace : $(<\mathrm{LOQ})$ & & & &
\end{tabular}

$10 \mathrm{ng} / \mathrm{L}$ となるように添加して得られたクロマトグラムを Fig. 5 に示す. Fig. 5 (B) においてフルオシノロンアセトニ ドと同じ保持時間にピークが検出されているが, 確認イオ ン $[\mathrm{M}+\mathrm{K}]^{+}$のクロマトグラムではピークが全く検出され なかったため, フルオシノロンアセトニドのピークではな いと判断した. また, 同様に二プロピオン酸ベタメタゾン の保持時間付近にピークが検出されたが, 標準溶液の保持 時間と一致しなかったため, このピークは二プロピオン酸 ベタメタゾンのピークではないと判断した.

海に近い R1 地点で採水したサンプルでは, 酢酸ヒドロ コルチゾンと吉草酸ベタメタゾンが定量限界以下でわずか に検出された. また, 少し内陸の R2 地点においては, 酢 酸ヒドロコルチゾンが $8.6 \mathrm{ng} / \mathrm{L}$, 吉草酸ベタメタゾンが $2.6 \mathrm{ng} / \mathrm{L}$ ，デキサメタゾン及びベタメタゾンが定量限界以 下で検出された， R1 及び $\mathrm{R} 2$ サンプルの測定結果は同様な 傾向を示したが, R1 地点のほうが若干濃度レベルが低か った， R1 地点は海に近いため, 潮の干満によりかなり海の 影響を受けているのではないかと推測される.

$$
4 \text { 結 語 }
$$

質の同時多成分分析法の検討を行った，本測定系では，測 定対象物の標準溶液で得られた $r$ 及び RSD が 0.9971 及び 2.1 ～12.1\% と良好な結果が得られたため, 内部標準物質 を使用しなかった. 前処理には Sep-Pak ${ }^{\circledR} \mathrm{C} 18$ を用い, 試料 $1 \mathrm{~L}$ を用いることで定量下限值が $10 \mathrm{ng} / \mathrm{L}$ 以下となり，環 境中に存在する微量な医薬品のスクリーニング法として有 用であることが示された。 しかし，下水等非常に複雑な來 雑物質の多いサンプルにおいては，前処理について更なる 検討が必要であると考えられる.

また，環境サンプルとして河川水について，本分析法を 適用した結果, すべてのサンプルで数種類の副腎皮質ステ ロイドが数 $\mathrm{ng} / \mathrm{L}$ レベルで検出された. 医薬品は種類も多 く物性も様々であるため, 下水処理で除去されずそのまま 環境中へ放出された可能性が考えられる ${ }^{15)}$. また, 下水道 普及率が低く下水処理施設が整備されていない地域があ り, 下水道の普及や高次処理による有機物の分解等, 環境 に医薬品を排出しない方法の検討も必要と考えられる.

医薬品は, 医療や水産, 畜産を含め社会生活を送る上で 必要であり, 有用なものであるが, その医薬品が環境を污 染する可能性があるということを社会的に, 特に医療従事 者に認識されることが必要であると考える，それにより， 

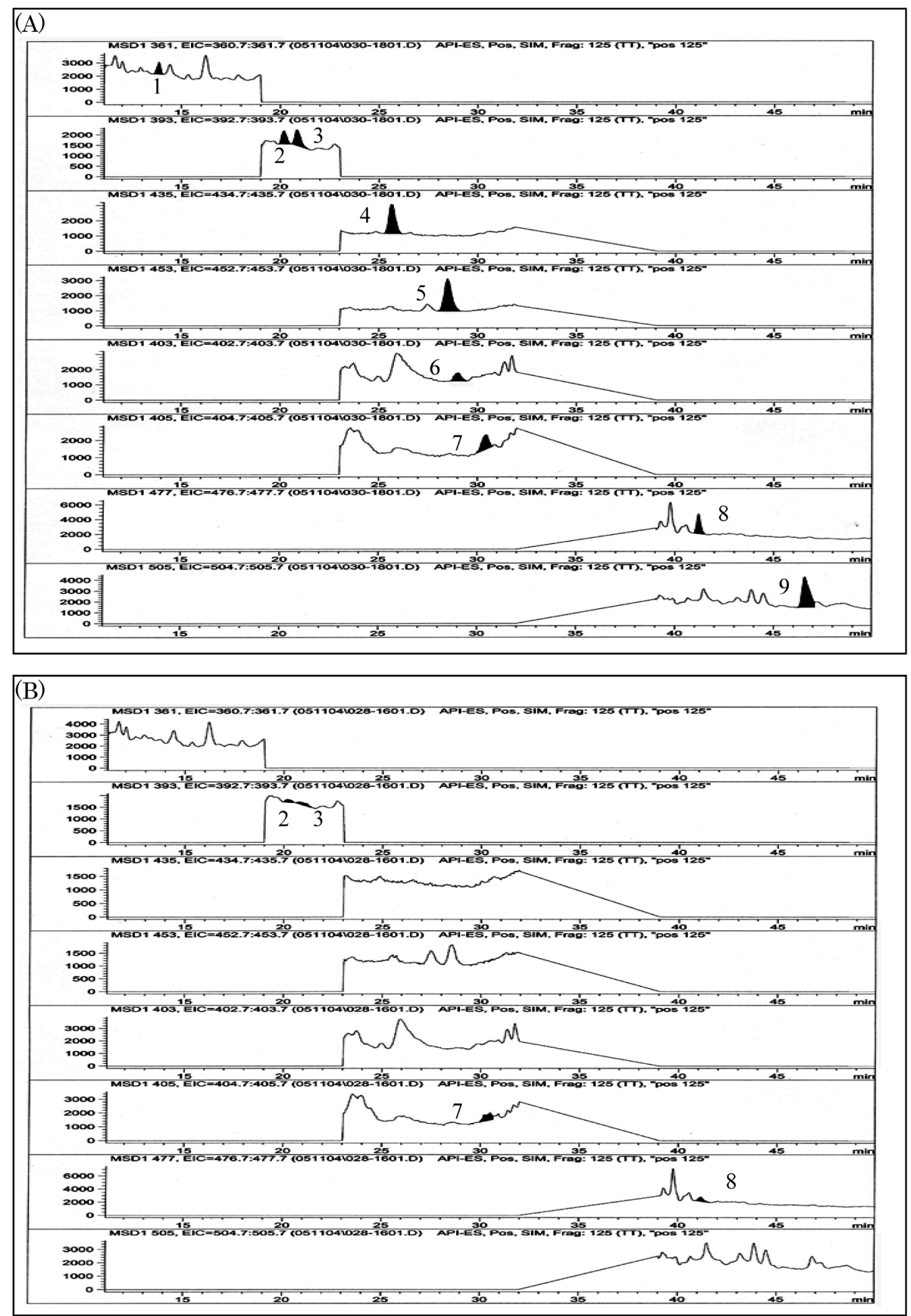

Fig. 5 Chromatograms of $10 \mathrm{ng} \mathrm{L}^{-1}$ standard solution added to R2 sample (A) and R2 sample (B) with SIM mode $\left([\mathrm{M}+\mathrm{H}]^{+}\right)$

1: Prednisolone, 2 : Dexamethasone, 3: Betamethasone, 4 : Triamcinolone acetonide, 5 : Fluocinolone acetonide, 6: Prednisolone acetate, $7:$ Hydrocortisone acetate, $8:$ Betamethasone valerate, 9 : Betamethasone dipropionate 
医薬品の適正な使用と使用済み医薬品の回収等を促進し, 環境に対するリスクを少しでも低減できるよう努力するこ とが今後, 求められてくるものと思われる.

$$
\left(\begin{array}{l}
2006 \text { 年 } 3 \text { 月, 日本薬学会 } \\
\text { 第 } 126 \text { 年会に扔いて発表 }
\end{array}\right)
$$

\section{文献}

1) M. J. L. Alda, S. Díaz-Cruz, M. Petrovic, D. Barcelo : J. Chromatogr. A, 1000, 503 (2003).

2) T. A. Ternes : Water Res., 32 (11), 3245 (1998).

3) T. Ternes, M. Bonerz, T. Schmidt: J. Chromatogr. A, 938, 175 (2001).

4) T. Heberer : J. Hydrol., 266, 175 (2002).

5) V. Koutsouba, T. Heberer, B. Fuhrmann, K. SchmidtBaumler, D. Tsipi, A. Hiskia : Chemosphere, 51, 69 (2003).

6) J. O. Straub : Toxicol. Lett., 131, 137 (2002).
7) H. Jones, N. Voulvoulis, J. N. Lester : Water Res., 36, 5013 (2002)

8) 石井善昭, 王 寧, 尹 順子: 環境化学, 14 (1), 127 (2004).

9) 清野敦子, 古荘早苗, 益永茂樹: 水環境学会誌, 27 (11), 685 (2004).

10) 清野敦子, 古荘早苗, 益永茂樹: 用水と廃水, 47 (2), 39 (2005)

11) 厚生労働省医政局：薬事工業生産動態統計年報 平成 14 年, じほう (2003).

12) 三田村邦子, 島田和武: 分析化学 (Bunseki Kagaku), 48, 401 (1999).

13) 中村 洋: “液クロ 彪の巻”, 日本分析化学会 液 体クロマトグラフィー研究懇談会編, p. 127 (2004).

14) Susan Budavari (Ed.) : “The Merck Index, An Encyclopedia of Chemicals, Drugs, and Biologicals, 12th Ed.", (1996), (MERCK \& CO., INC.).

15) S. A. Snyder, P. Westerhoff, Y. Yoon, D. L. Sedlak : Environ. Eng. Sci., 20 (5), 449 (2003).

\title{
Determination of Corticosteroids in Environmental Water by Liquid Chromatography/Mass Spectrometry
}

\author{
Aoi MiYamoto $^{1}$, Yuko Kitaichi ${ }^{2}$ and Kazuo UchikURA ${ }^{1}$ \\ ${ }^{1}$ School of Pharmacy, Nihon University, 7-7-1, Narashinodai, Funabashi-shi, Chiba 274-8555 \\ ${ }^{2}$ Graduate School of Parmacy, Nihon University, 7-7-1, Narashinodai, Funabashi-shi, Chiba 274-8555
}

(Received 30 October 2009, Accepted 7 January 2010)

The determination of 9 corticosteroids in environment samples by a liquid chromatography/ mass spectrometry (LC/MS) was established, and was applied to river water. After river-water samples were filtered through a glass microfiber filter, GF/B, these filtrates were passed through a solid-phase extraction cartridge and extracted corticosteroids. Extraction solutions were concentrated and re-fused by acetonitrile, and the resulting extracts were directly injected into the LC/MS system. The mobile phase used was acetonitrile - ammonium acetate buffer (pH 5.0) for gradient elution and detected by MS. Under the optimum analytical conditions, the correlation coefficients of calibration curves were more than 0.9971 , and the limits of detection $(S / N$ $=3$ ) were in the range of $0.7 \sim 2.4 \mathrm{ng} / \mathrm{L}$. The recoveries of corticosteroids from river water spiked at $10 \mathrm{ng} / \mathrm{L}$ were $56.2 \sim 110 \%$. This method was satisfactorily used for the determination of corticosteroids in river-water samples.

Keywords : corticosteroids ; liquid chromatography/mass spectrometry ; solid-phase extraction. 